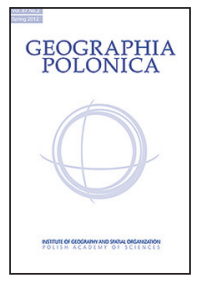 \\ INSTITUTE OF GEOGRAPHY AND SPATIAL ORGANIZATION \\ POLISH ACADEMY OF SCIENCES \\ www.igipz.pan.pl \\ www.geographiapolonica.pl
}

\title{
A NETWORK APPROACH TO TRANSBORDER COOPERATION STUDIES AS EXEMPLIFIED BY POLAND'S EASTERN BORDER
}

\section{Sylwia Dołzbłasz}

Department of Spatial Management, Institute of Geography and Regional Development University of Wrocław Kuźnicza 49-55, 50-138 Wrocław: Poland e-mail: sylwia.dolzblasz@uwr.edu.pl

\begin{abstract}
The work detailed in this article sought to determine the nature of the transborder cooperation ongoing in Poland's eastern borderland, focusing in particular on the transborder network. Research encompassed analysis of the scope of cooperation in terms of subject matter and type of beneficiary, as well as analysis of the transborder cooperation network using SNA. All beneficiaries and projects pursued under the Poland-BelarusUkraine 2007-2013 Cross-Border Cooperation Programme within the framework of the European Neighbourhood and Partnership Instrument were examined. Cooperation structures in the Polish-Ukrainian-Belarusian borderland area were then compared with those in the Polish-Czech and Polish-Slovak border areas. Results showed that, while the pursuit of common projects contributed to intensified connections in the Polish-Belarusian-Ukrainian borderland area, the transborder cooperation is much influenced by the strong formalisation of the EU's external border, and by formal-legal regulations in the neighbouring countries. The cooperation network in the eastern borderland of Poland thus differs greatly from those in the south.
\end{abstract}

\section{Key words}

transborder network • cross-border cooperation • EU external border • Poland-Belarus-Ukraine borderland

\section{Introduction}

Transborder cooperation is a very important element shaping borderlands, and within it a special role is played by projects implemented under EU Cohesion Policy. Though not the only form of cooperation, it often assumes great importance and represents a starting point for the development of other transborder activities, be these either formal or informal. A consequence of their implementation, especially in the long term, will thus be transformation of the socio-economic sphere in the borderland area, and in particular a shaping of transborder network connections.

With Poland's accession to the EU, the situation in this borderland area changed somewhat, above all because the accession gave 
rise to a situation in which this and other Polish borders became external borders of the European Union.

More generally, such border areas neighbouring non-European Union member states are known to feature among the regions of the Community least developed economically, with the consequence that cross-border cooperation is deemed of particular importance here. While cross-border Co-operation Programmes and the shaping of international links may indeed contribute greatly to social and economic activation, the implementation of cooperation across the EU's external frontier seems like a greater-than-usual crossborder challenging, given the formal and legal nature of the barrier, as well as the presence of less-developed regions of centrally-governed countries in which social orders are unique and foreign policies fairly closed.

\section{The objective and scope of the study}

The main aim of the work described here has been to analyse the scope and nature of cooperation in the Polish-Ukrainian-Belarussian borderland, and to understand basic characteristics of the relationships between Polish, Ukrainian and Belarussian beneficiaries of transborder Co-operation Programmes. The structures characterising transborder cooperation in Poland's eastern borderland have also been compared with those functioning in the southern borderland. Specifically, work assessed the practical implementation of cross-border cooperation under the PolandBelarus-Ukraine 2007-2013 Cross-border Cooperation Programme forming part of the European Neighbourhood and Partnership Instrument (ENPI), in support of European Neighbourhood Policy (ENP). The analysis took in project structure by type, as well as the institutional structure of Programme beneficiaries. The relationships between actors involved in implemented projects have also been investigated, with social network analysis conducted to that end. The research concerns the area of eastern Poland and western Ukraine and Belarus encompassed by the Programme under analysis.

Data here concern 111 projects implemented under the Poland-Belarus-Ukraine 2007-2013 Cross-border Cooperation Programme, as well as 258 institutions engaged in their implementation (including 132 in Poland, 90 in Ukraine and 36 in Belarus) 1 . The comparative analysis in turn used data on projects and project beneficiaries under the Poland-Slovak Republic and Czech Republic-Poland 2007-2013 Cross-border Cooperation Programmes (respectively 109 projects and 244 institutions and 250 projects and 340 institutions).

The research includes analysis of the nature of cooperation being engaged in (by thematic structure of projects, types of beneficiary and types of project consortium), as well as the transborder cooperation network present in the Polish-Ukrainian-Belarussian borderland. Key features of this network were identified using Social Network Analysis (and UCINet software). Assumptions made for the purposes of this study are that network nodes are institutions participating on the Cooperation Programmes, while edges are transborder project participation. Connections are considered non-directed, while researched networks belong, and are multimodal in character. Analysis encompasses selected parameters describing networks, such as network density, nodes' degree, betweeness and coreness. A further important element of this work is analysis of the spatial distribution of transborder cooperation partnerships.

\section{The network approach in border studies}

Interest in borders and borderlands increased in the 1990s in Poland and other CEECs, century, with the direct trigger being the political transformations in this part of Europe initiated in 1989. The latter obviously had

\footnotetext{
${ }^{1}$ Data as for 1st July 2015 obtained from the Joint Technical Secretariat; Technical Assistance and Small Project Fund projects have been omitted.
} 
a tremendous influence in transforming the roles and functions of borders, as well as the functioning of transborder areas, e.g. in the socio-economic and spatial spheres. As transborder cooperation became very popular, cooperation between Poland and neighbour countries is documented relatively widely in the literature. Numerous studies (e.g. Miszczuk \& Kawałko 2005; Krok \& Smętkowski 2006; Komornicki \& Miszczuk 2010; Miszczuk 2015) have involved Poland's eastern borderland with Belarus and Ukraine, or else the southern - Polish-Czech or Polish-Slovak - borders (e.g. Potocki 2009; Vaishar et al. 2013; Więckowski et al. 2012; Więckowski 2013; Dołzbłasz 2016), with the focus on environmental, tourist-related and transport aspects first and foremost. However, as transborder cooperation developed further, more studies (e.g. Olejniczak 2008; Borowczak et al. 2012; Gorzelak \& Zawalińska 2013; Dołzbłasz \& Raczyk 2015) began to concern themselves with complex analysis of the socio-economic and spatial dimensions to integration. Notwithstanding the ever-wider application of the network approach, very few studies have taken in Polish borderlands, while this shortfall is all the more observable where empirical studies using the tools of Social Network Analysis (SNA) are concerned.

As Johnson (2011) argues, ever-greater importance has recently been attached to analyses of processes and relationships (inter alia cooperative and competitive relationships) in borderlands, as opposed to just studies of borders in the strict sense (Dołzbłasz \& Raczyk 2016). As a result of changes following the post-Cold War era, intensified integration processes in Europe, and the globalisation of the world economy, the approach to cooperation has been modified considerably. Nowadays, borders are perceived more broadly, not only from a spatial perspective, not only as a physical barrier separating one country from another, but also as a socio-spatial construct articulating existing discrepancies (van Houtum 2005).

Strihan (2008) shows how a network approach may alter a study's perspective by allowing borders to be perceived as areas with special patterns of interaction able to exclude or bond communities, as opposed to merely regions that separate bundles of homogeneous social units. Under this approach, border regions are treated as areas of diffusion that do not divide but merge, with the border itself being as much a bridge as a barrier. However, the way in which 'spaces of flow' emerge in cross-border regions (if they do so at all) depends on many factors, with the result that cross-border networks are for example seen to be shaped differently in Europe and North America (Blatter 2004).

Network analysis is proving its worth when it comes to the assessment of programmes and projects intended to shape relationships (Olejniczak et al. 2008; Płoszaj 2013). It may provide new information on the way connections between network actors are structured, in this way proving of use to the process shaping cooperation systems and designing organisational structures (Provan et al. 2005). It also allows key entities engaged in a network to be identified, along with their scope of cooperation and significance (Walther \& Reitel 2012).

The network approach has been applied in researching international business connections (Yeung 1998; Hsu 2005), as well as the business networks present in cross-border regions of Eastern Europe (Leick 2012). Strihan (2008) used SNA to analyse the significance of ethnic connections in shaping a transborder network between companies in Belgium. The issue of the shaping of cooperation networks in borderlands was in turn taken up by Durand and Nelles (2012) among others, in relation to the Lille-Kortrijk-Tournai Eurometropolis. SNA allowed the degree of network development to be assessed, along with the significance of actors and the role each played. It also helped evaluate the extent to which an international border affected the management of transborder public transport. The study in question was thus based on interviews with entities engaged in the implementation of public transport policy. An analogous study was conducted by Walther 
and Reitel (2012) as well as Dörry and Decoville (2012) in the Basel region, as located within the transborder region of Luxemburg (LUX-LOR-SAR).

Studies on the shaping of personal contacts and social organisation networks were in turn undertaken by Lara-Valencia (2011) - in the case of the American-Mexican borderland, and by González-Gómez and Gualda (2014) - in the case of the borderland areas of Andalusia-Algarve-Alentejo and Southern Finland-Estonia. Studies of transborder connections among political representatives of six Euroregions along the Hungary-Slovakia, Sweden-Norway and Austria-Germany borders were conducted by Svensson (2013), with a detailed SNA study carried out on the basis of interviews, and a focus on the issue of governance.

In Poland, border studies have included an evaluation of partner networks under the INTERREG IIIB CADSES Programmes which was conducted by Olejniczak et al. (2008). The SNA method was also used by Płoszaj (2014), to analyse cross-border cooperation in the Podkarpackie and Lviv regions of Poland and Ukraine.

The application of the network approach to the study of transborder cooperation connections is definitely justified, as this is by nature network-like in character, with knowledge as to the nature of relationships in borderlands being broadened in the process. While van Houtum (1999) notes that the development of transborder cooperation networks is one of the Interreg Programme's main specified objectives, some studies show that transborder cooperation networks in European borderlands are still underdeveloped (Koschatzky 2000; Strihan 2008).

\section{Factors affecting cooperation along Poland's border with Ukraine and Belarus}

Formalised forms of cooperation in Poland's eastern borderland (which is simultaneously the external border of the EU) are relatively new. Until 1991, the eastern border of Poland was closed, with a very low 'permeability' not conducive to mutual contacts. Such a state of affairs led to a progressing socio-economic peripherisation of these regions and that remains noticeable even today (Miszczuk 2015), notwithstanding the socio-political transformation taking place in Poland and neighbouring countries in the 1990s, and entailing reconfigurations more favourable to cooperation between various borderland actors. Poland's 2004 EU accession represented a further breakthrough in this respect, with its eastern borderland coming within the INTERREG IIIA/TACIS CBC 2004-2006 Neighbourhood Programme for Poland, Belarus and Ukraine, which offered great chances for transborder activity to be accelerated ${ }^{2}$. Another programme was the Poland-Belarus-Ukraine 2007-2013 Cross-border Cooperation Programme forming part of the European Neighbourhood and Partnership Instrument (ENPI), complete with a budget of 202.9 million EUR (including 186.2 M EUR from EU Funds). This initiative aimed at enhanced cooperation between the European Union and partner countries, through fostered integrated and sustainable regional development (Wesselink \& Boschma 2017). It is worth noting that more funds were allotted under this Programme than in the previous programming period, albeit with project participants expected to cooperate even more closely.

Where non-system determinants are concerned, a low level of socio-economic development (Smętkowski 2015), underdeveloped transport connections and border crossings and the requirement that citizens of Ukraine and Belarus have a visa to enter Poland all still constitute significant hindrances to cooperation. The strong formalised nature of the eastern border makes it much more difficult to initiate cooperation at grassroots level than to pursue cooperation via supralocal institutions. Indeed, all the problems associated with

\footnotetext{
${ }^{2}$ Most projects implemented concerned transport, social and environmental infrastructure, as well as cultural cooperation and tourism (Dołzbłasz \& Raczyk 2015).
} 
border functioning are overcome more readily by central institutions or regional authorities than by, for example, cultural institutions or schools. This reflects the centralised nature of the administrative network in Belarus and Ukraine (Pysarenko 2016; Rudenko et al. 2016). Moreover, cooperation on the eastern border is largely dependent on the political situation (Haase \& Wust 2004; Wiering \& Verwijmeren 2012).

One of the most important factors conducive to cooperation is the presence of a relatively fuzzy cultural barrier that inter alia reflects the existence of (Belarussian and Ukrainian) national minorities on the Polish side, as well as Polish minorities on the other side of the border, plus a common history, knowledge of the language and family connections. In turn, factors hindering cooperation include negative experiences from history, most notably the history common to Poland and Ukraine. Key cooperation motifs in turn include very precious nature reserves, supranational transport routes, numerous monuments of common history, and cooperation between academic centres (Proniewski 2008; Miszczuk 2015).

Poland's southern borderland enjoys much more favourable conditions for cooperation, inter alia arising out of Polish, Czech and Slovak membership of the EU and its Schengen Zone, as well as similarities between political and economic systems, culture and localgovernment functioning. A further important element affecting cooperation relates to the presence of mountainous regions in these border areas. On the plus side this is seen to favour the development of transborder, while on the minus side it does tend to represent a transport barrier. Other elements definitely discouraging transborder relationships from forming include a paucity of transport connections along some stretches, as well as an attitude that favours competition as opposed to cooperation). Nevertheless, the situation of institutions engaged in Polish-Ukrainian-Belarussian cooperation is far more complex than this (Dołzbłasz \& Raczyk 2015).

\section{Cooperation network in the borderland}

The Polish-Ukrainian-Belarusian borderland is dominated by the public-sector institutions that together account for about $75 \%$ of all beneficiaries of transborder projects (with local and regional administration on $49 \%$ and central administration on 26\%). The main reason for this is the marked centralisation of the administrations on the Belarusian and Ukrainian sides. However, the participation of nongovernmental institutions (mainly from Poland and Ukraine) in as many as $19 \%$ of cases indicates increased activity in transborder relationships (as compared with the previous period), as well as the acquisition of the experience necessary if the problems arising out of the marked formalisation of the state border are to be contended with.

In regard to the classification of the structure of beneficiaries in terms of objective of activity and country of origin, certain characteristic features are to be observed. The participation of Belarussian local authorities in transborder projects seems to be very limited, in direct reflection of the country's political situation, which accounts for the high participation of centralised units of administration, as well as scientific and healthcare institutions (all in the public sector) at levels of $16 \%, 13.5 \%$ and $13.5 \%$ respectively. Where Polish and Ukrainian beneficiaries are concerned, the structure is dominated by local authorities, though an important role is also played by the central-administration authorities, scientific units, and institutions associated with healthcare and the business environment. Worth noting is the relatively high level of participation of NGOs of diversified activity profiles, albeit with a majority concerned with ecology.

The beneficiary structure characteristic of the southern borderland reveals distinctly fewer institutions under central-government control (only $1.5 \%$ in the Polish-Slovak Programme and $5.5 \%$ in the Polish-Czech one), but also scientific institutions (3-6\%), those involved in health care $(1,7 \%$, Polish-Czech 
Programme only) and NGOs (15\%). There was a much clearer dominance of local authorities (accounting for 46 and $57 \%$ in the PolishCzech and Polish-Slovak borderlands respectively), especially when regional-government organisational units (on 6-11\%) were added in. Thus, where regional and local government units are rather weak, different kinds of institution play a more significant role, be these government-related or non-government. In turn, where the bodies in question have numerous competences and a wide array of tasks, they tend to dominate cooperation structures.

The relationships between actors within the Poland-Belarus-Ukraine Cross-border Programme framework are clearly dominated by bilateral connections. Only $7 \%$ of projects were trilateral, implemented by Polish, Ukrainian and Belarusian partners. Moreover, despite the Programme's emphasis on multi-partner collaboration, it is projects with only two partners that occur most frequently (in 45\% of cases). One reason is that cross-border cooperation along Poland's eastern border is in its initial phase of development, such that network projects involving many partners from different countries are a matter for more intensive cooperation between experienced actors. However, cooperation in the southern borderland is also seen to be dominated by two-partner consortia, suggesting a general difficulty with the establishment of wider project consortia among Polish actors in transborder cooperation.

Some similarities between types of actors in project consortia can be observed. Units of the central administration join local and regional authorities in engaging in cooperation with similar partners across the border very frequently. This reflects both organisational structure and administrative constraints. In contrast, cultural institutions, NGOs and business-environment institutions for example pursue joint projects with various types of partner, since they exhibit greater openness at the time of selection. As a similar situation characterises the Polish-Czech and Polish-Slovak borderlands, the existence of general tendencies in this respect is indicated.

Polish institutions prevail among the beneficiaries of the Poland-Belarus-Ukraine cooperation network. This is particularly noticeable as regards actors' roles within project consortia, as Polish beneficiaries account for almost $76 \%$ of lead partners. Polish institutions have longer experience in international cooperation, and have better-developed organisation and financial capacity for the running of transborder projects. Moreover, the functioning of governance at local and regional levels is also a factor affecting the activity of Polish actors significantly. The activity of institutions from each country is found to be comparable in the Polish-Czech and Polish-Slovak borderlands.

The structure of the projects in the PolandBelarus-Ukraine Programme analysed in terms of their thematic scope revealed a dominance of infrastructural activities, among which most (over 24\%) concerned social infrastructure activities, while $9 \%$ entailed developing the potential of firefighting services and the police (Fig. 1). These projects are mainly managed by public administration units given the afore mentioned truth that all obstacles connected with the highly-centralised systems in Belarus and Ukraine and concerning a Schengen border can be overcome more readily by central institutions or regional authorities, while creating considerable problems for local associations and cultural institutions. A positive feature is a relatively high (11\%) level of participation of projects in the area of research and innovation, as pursued mainly by scientific institutions, as well as projects in the field of environmental infrastructure $(9 \%)$, given that the Programme embraces many areas of great value in terms of nature conservation. It is worth noting the quite considerable (13.5\%) participation of tourism-related projects. The dominance of social, road-related and environmental-infrastructure projects reflects immense investment needs in these fields, and an excessive local and regional government and central administration focus on infrastructural investments. 


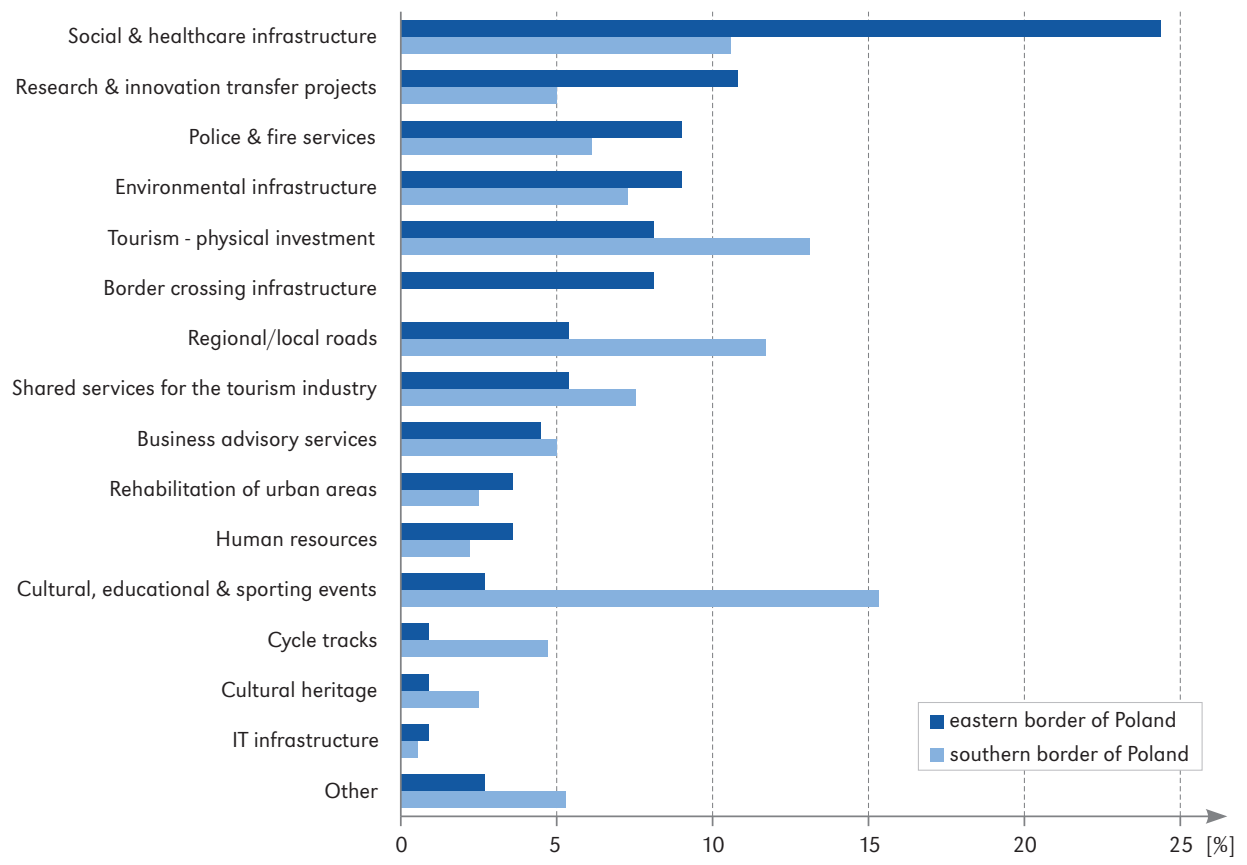

Figure 1. Structure of projects within 2007-2013 Cross-border Cooperation Programmes, by dominant thematic scope

Source: based on data from the Joint Technical Secretariat (JTS).

In terms of scope as regards subject matter, the projects in the southern borderland do differ characteristically from those in the eastern borderland. While significant, activities relating to social and healthcare infrastructure only half as frequent in the south. The role of scientific projects was not as important, with only a $5 \%$ share. The role of investment in tourism is greater in the southern borderland (undoubtedly in connection with its natural conditions and tourist attractions), but road investments were also twice as frequent, and cycle tracks four times so. What distinguishes the southern borderland most is a high participation of the cultural, educational and sporting undertakings so much predicated on joint participation by inhabitants from neighbouring countries. Events featuring people's direct involvement are far easier to run along the 'non-formalised' southern border and are probably more significant to the institutions engaged in transborder cooperation (mainly local authorities) ${ }^{3}$.

The main factors shaping the spatial distribution of cooperation beneficiaries (with projects in most cases implemented in the same places) was a location near an urban centre, or to a lesser extent the factor involving proximity of the border (Fig. 2). A vast majority of beneficiaries were located in the borderland's largest cities (e.g. Lublin, Rzeszów, Lviv, Grodno, Lutsk, Brześć and Biała Podlaska). Exceptions were Białystok and Kowel,

\footnotetext{
${ }^{3}$ It is worth noting that various types of activities may be being pursued under a single project (including those of an investment or non-investment type). As projects were categorised in relation to financial commitment for the purposes of this study, scope as regards subject matter was assigned in line with the largest sums allotted. A majority of projects (mainly of the investment type) were accompanied by so-called soft activities (e.g. events, training sessions andpromotional activities).
} 
whose roles were not as significant as their potential and proximity to the border might suggest. No significant spatial concentration was observed anywhere in the borderland. The factor of proximity of the border did not play a significant role in initiating cooperation. Interestingly, although the presence of border crossings in the spatial distribution was noticeable, it was not of a dominant nature. A greater concentration of beneficiaries was found near Hrubieszów and Włodzimierz Wołyński (i.e. the Zosin-Uścitug border crossing), as well as Brześć and Biała Podlaska (which are joined by the road through Terespol) or Yavoriv (on the Ukrainian side), near the border crossing in Korczowa. Single projects were being implemented in Dorohusk and Włodawa. The relatively high concentration of beneficiaries to be noted in the Białowieża/Belovezhskaya Forest region is indicative of the significant role nature conservation and environmental protection play in transborder cooperation.

Cooperation between institutions based in the borderland's most important cities formed the main axes of connections. Given the limited activity of Belarussian institutions, a markedly greater number and intensity of connections was noted in the borderland's southern part. This effect was so marked that, notwithstanding the proximity of Belarus, Polish institutions located in the northern

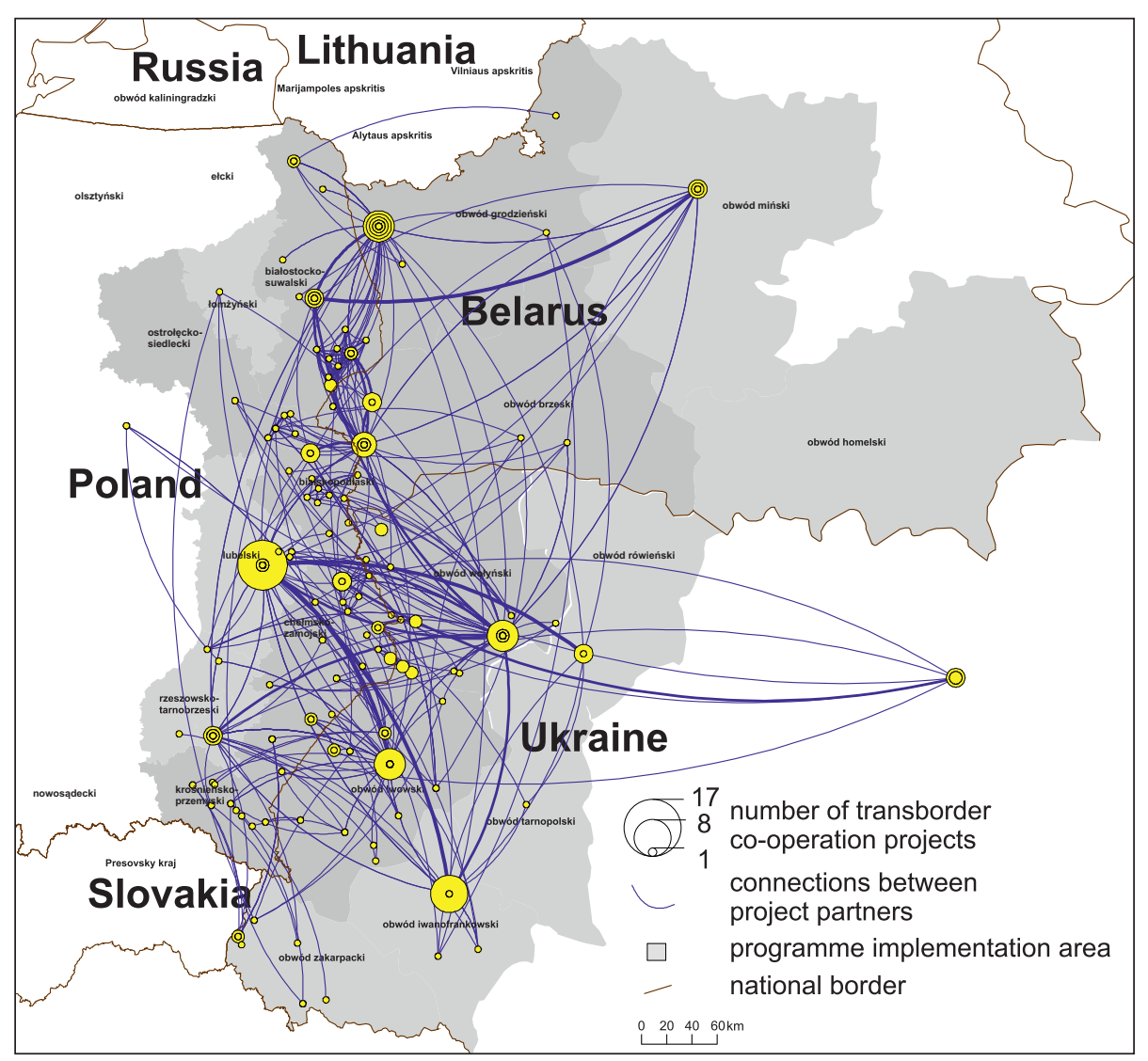

Figure 2. The spatial distribution of project beneficiaries by number of projects and connections within projects under the Poland-Belarus-Ukraine 2007-2013 Cross-border Cooperation Programmes.

Source: based on data from the Joint Technical Secretariat. 
part of the borderland still had more connections with Ukrainian partners. As a considerable number of connections concerned units in remote locations, the vast majority of projects are seen to have had little impact in shaping actual transborder relations, with relationships between final beneficiaries (usually inhabitants) proving scarce. The densest network of connections was observed in the area between Lublin, Lutsk and Lviv (with institutions in these cities connected, but also rural and urban areas between them). It was also characteristic for non-Minsk-based Belarussian institutions to be located near the border, this perhaps indicating a lack of interest in cooperation on the part of institutions further from the border. The weakness of most Polish-Belarussian connections is manifested in the fact that only near-border institutions engage actively in transborder cooperation. Areas of activity were markedly larger on the Polish and Belarussian sides. The most important cities of the borderland, especially on the Ukrainian and Belarussian sides, form areas specialising in transborder projects While this can be seen as favourable, since it may contribute to a promoting of the idea of cooperation in other parts of the borderland also, it may also pose the threat of cooperation being limited to isolated urban areas.

Compared with the spatial distribution of cooperation in the Polish-Czech and PolishSlovak borderlands, that in Poland's eastern borderland does not entail such an important role for the proximity of borders. In the southern borderland, beneficiaries of transborder projects concentrate close to the state border, with differences reflecting a far greater Programme implementation area in the eastern borderland, combined with the aforementioned high level of formalisation of the state border. However, in the southern borderland, an additional element conducive to concentration near the border is the low level of formalisation, the shared mountainous areas and the large number of towns and cities. In the case of projects in the eastern borderland, beneficiaries located close to border crossings emerged as definitely more active.
In the south, where fuller freedom to cross the border is enjoyed, a greater number of institutions took advantage of the closeness of partners on the other side of that non-formalised state border.

To assess the process by which transborder cooperation connections are shaped, an SNA analysis has been conducted at the macro level, including all beneficiaries engaged in projects under the researched Programme. Moreover, research on nodes refers to selected measures of centrality. The density of cooperation networks within the Poland-Belarus-Ukraine Programme proves to be very low (at 0.015, where network density expresses the ratio of the number of relationships actually present to all possible relationships in a network of the given size). This is influenced by the prevalence of bilateral projects, and the fact that most institutions are implementing just one. In fact, the measure assumed a similarly low value in the Polish-Czech borderland (0.012) and the Polish-Slovak borderland (0.024). The trilateral nature of the programme did not contribute to a further lowering of the density measure. The decisive factor was generally one-off participation of a particular institution under the Programme, mostly through cooperation with just a single partner. To identify institutions forming the most important nodes of the transborder network in the Polish-UkrainianBelarussian borderland reference was made to such centrality measures as the degree centrality (i.e. the number of connections within a node), betweenness centrality (measures how often a node appears on shortest paths between nodes in the network). Moreover, the occurrence of main components and peripheries has been analysed, and coreness defined (to distinguish nodes belonging to the nucleus of the network or located peripherally). On the above basis, 11 borderland institutions were classified as nodes of greatest importance (Tab. 1). Among them are both institutions of local administration (mainly cities), government institutions (on the Belarussian side), and institutions in culture and science as well as Euroregions. 
Table 1. Institutions characterised by highest values for selected measures characterising the PolishBelarussian-Ukrainian transborder cooperation network within the EINP 2007-2013 framework

\begin{tabular}{|c|c|c|c|c|}
\hline Institution & Degree & Coreness & Institution & Betweenness \\
\hline $\begin{array}{l}\text { Brest Oblast Office of the } \\
\text { Ministry of Emergency } \\
\text { Situations of the Republic } \\
\text { of Belarus }\end{array}$ & 24 & 0.3028 & $\begin{array}{l}\text { Yanka Kupala State University } \\
\text { of Grodno }\end{array}$ & 529 \\
\hline City of Lublin & 16 & 0.2019 & $\begin{array}{l}\text { "Brama Grodzka - Teatr NN" } \\
\text { Centre }\end{array}$ & 500 \\
\hline Czeremcha Municipality & 15 & 0.1893 & Lviv City Council & 366 \\
\hline $\begin{array}{l}\text { 'Puszcza Białowieska' } \\
\text { Euroregion }\end{array}$ & 15 & 0.1893 & $\begin{array}{l}\text { Lutsk City Council Executive } \\
\text { Committee }\end{array}$ & 342 \\
\hline \multirow[t]{2}{*}{$\begin{array}{l}\text { Ivano-Frankivsk City Council } \\
\text { Executive Committee }\end{array}$} & 15 & 0.1893 & Bug Euroregion & 278 \\
\hline & & & $\begin{array}{l}\text { Suwałki Chamber } \\
\text { of Agriculture and Tourism }\end{array}$ & 266 \\
\hline
\end{tabular}

Source: using UCINet 6.589 on the basis of JTS data.

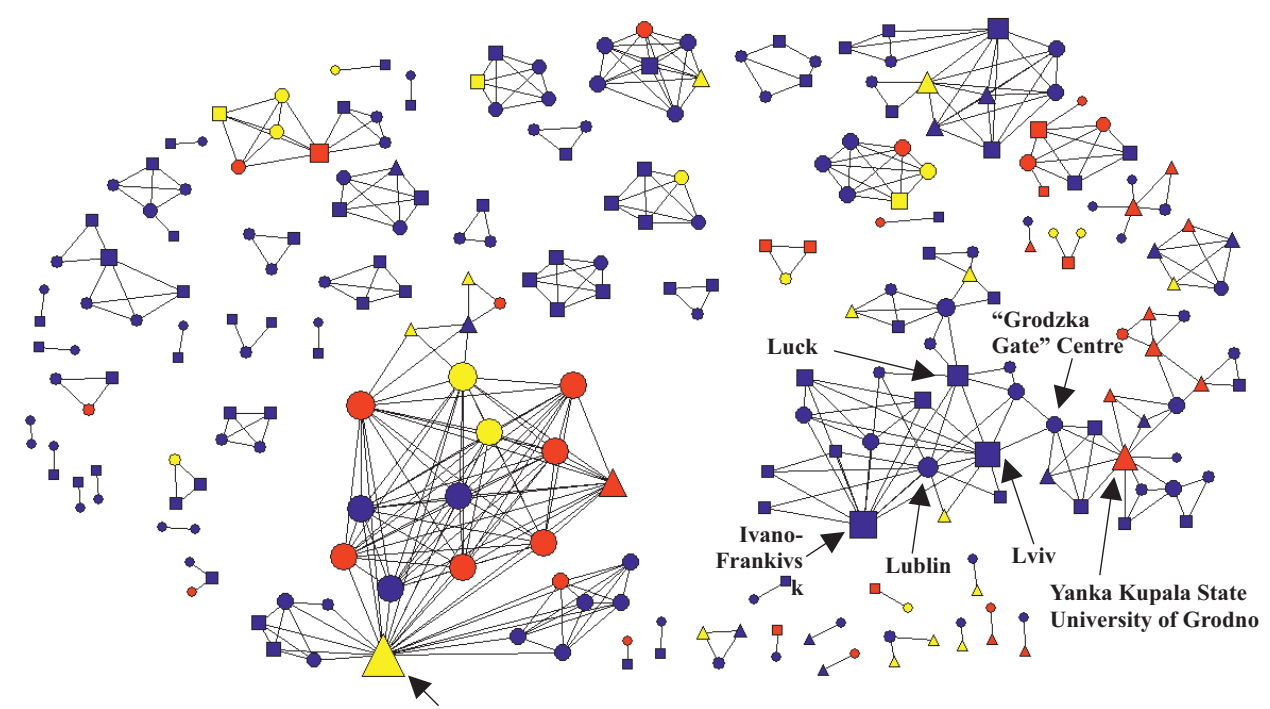

Brest Oblast Office of the Ministry of Emergency

Situations of the Republic of Belarus

shapes - countries:

circles - institutions from Poland

squares - institutions from Ukraine

triangles - institutions from Belarus colours - distances from the national border:

yellow - up to $10 \mathrm{~km}$

red - 10-20 km

blue - more than $20 \mathrm{~km}$

Figure 3. The transborder cooperation network under the Poland-Belarus-Ukraine 2007-2013 Crossborder Cooperation Programme by degree, country and distance from the national border

Source: using NetDraw, on the basis of data from the Joint Technical Secretariat. 
It is worth mentioning that high centrality values for particular nodes are frequently connected with a large number of projects implemented. However, this is not always the case, as beneficiaries participating in a large number of projects but implemented with the same partner look less significant from the point of view of networking than those with a smaller number of projects implemented in cooperation with a greater number of partners who each have a number of other contacts of their own. This was true of the Polish-Ukrainian-Belarussian borderland, where Lublin played host to 8 projects, while Grodno Oblast Teaching Hospital, Lutsk City Council, Lviv City Council and Ivano-Frankivsk City Council were all involved in 5, and Yanka Kupala State University of Grodno and the Brest Oblast Office of the Ministry of Emergency Situations of the Republic of Belarus in 4 each. Grodno Oblast Teaching Hospital was not counted among the network's key nodes as it has implemented projects by way of an isolated bilateral partnership. The situation from the point of view of between-ness centrality was very interesting, highlighting as it did the institutions appearing most frequently on the route between two other nodes unconnected with one another. This is indicative of a significant role in the cooperation network, even where the number of projects is relatively small.

The visualization (reproduced as Fig. 3) reveals a very dispersed network of $55 \mathrm{com}$ ponents (of which the main one groups just 45 institutions). This was the consequence of numerous pairs of institutions implementing a single project only. Nodes' importance also depend on their position within the transborder network. A role as a "cutting point" makes such nodes especially significant, as they allow for the flow of information within a vast number of network nodes. Moreover, without the connections offered by the node (or nodes) in "cutting point" positions, the whole network would have far more components and be of even lower density. From this point of view, an important role in the PolishBelarussian-Ukrainian transborder network was played, not only by public administration (the City of Lutsk and the Brest Oblast Office of the Ministry of Emergency Situations of the Republic of Belarus), but also - very significantly - by institutions of other types, e.g. Yanka Kupala University and the "Grodzka Gate" Centre.

\section{Conclusions}

Given its high degree of formalisation, the external border of the EU constitutes a significant barrier between neighbouring countries. It should be the role of programmes co-financing transborder cooperation to counteract the negative effects of this. The results obtained suggest that, while common projects do help intensify connections in borderland areas, it is the nature of the given border and formal-legal regulations applying in neighbouring countries that influences the shaping of transborder cooperation. The cooperation network along Poland's eastern border differs from that in the southern borderland in being markedly imbalanced where activity of the actors from particular countries is concerned. Moreover, the sector of government administration, scientific and healthcare institutions is observed to be of greater significance (as actors of these types find problems connected with crossing the Schengen border easier to overcome). There is a clear need to support cooperation between cultural institutions, schools and institutions of the business environment. However, like its southern counterpart, Poland's eastern borderland is dominated by social-infrastructure projects, albeit with greater participation, given the more limited significance there of tourism- and culture-related projects. Beneficiaries of transborder programmes can thus be said to prefer projects seeking to meet the practical needs of individuals both on the Polish side and across the border. The need in the less developed eastern borderland is generally greater. Due to the strong role of the eastern border as a barrier to cooperation, the factor of proximity to that border on the Polish side proves much less important than in the south, when 
it comes to the process by which cooperation spatial structures are shaped. The main factor behind the concentration of institutions engaging in cooperation is found to be urban location and (to a lesser extent) the proximity of border crossings. The influence of environmental aspects is also more limited than with the Czech Republic and Slovakia, though still visible, e.g. in the form of greater participation in projects involving environmental infrastructure, as well as the activity of beneficiaries from the internationally recognised protected area of the Białowieża/Belovezhskaya Forest.

The density of the connection network characterising transborder programmes was found to be very low in both the eastern and southern borderlands, this indicating a low level of networking when it comes to cooperation in Polish borderlands. A good point is that key institutions in the eastern borderland

\section{References}

BLATTER J., 2004. From 'spaces of place' to 'spaces of flows'? Territorial and functional governance in cross-border regions in Europe and North America. International Journal of Urban and Regional Research, vol. 28, no. 3, pp. 530-548.

Borowczak A., Czerniejewski B., Kozak M., KozicKı B., Kościelecki P., Ledzion B., Olejniczak K., Pander W., Płoszan A., Weremiuk A., WolañSKI M., 2012. Wyzwania i cele dla programów wspótpracy transgranicznej z udziałem Polski po 2013 r. Wrocław-Warszawa: Ministerstwo Rozwoju Regionalnego.

DołzBŁASZ S., RACZYK A. 2015. Different borders different cooperation? Transborder cooperation in Poland. Geographical Review, vol. 105, no. 3, pp. 360-376.

DotzBtASZ S., RacZYK A. 2017. Transborder cooperation and competition among firms in the Polish-German borderland. Tijdschrift voor Economische en Sociale Geografie, vol. 108, no. 2, pp. 141-156.

DörRY S., DeCOVILle A., 2012. Transportation policy networks in cross-border regions. First results from a social network analysis in Luxembourg include Polish and Ukrainian, as well as Belarussian units. Also important is the presence among them of various types of institution. From the point of view of the network of connections, the diversity of key units was greater than in the southern borderland, with the local and regional administrations predominant. Therefore, despite a greater number of units from the public-administration sector being present among the actors in the PolishUkrainian-Belarussian network of transborder cooperation, it is apparent that the development of border connections is highly dependent on the activation of institutions from outside the sector.

\section{Editors' note:}

Unless otherwise stated, the sources of tables and figures are the authors', on the basis of their own research.

and the Greater Region. CEPS/INSTEAD Working Paper, No 2012-22.

Durand F., Nelles J., 2012. Cross-border governance within the Eurometropolis Lille-Kortrijk-Tournai (ELKT) through the example of crossborder public transportation. CEPS/INSTEAD Working Paper, No 2012-16.

GonzÁlez-Gómeza T., Gualda E., 2014. Cross-border networks in informal and formal cooperation in the border regions Andalusia-Algarve-Alentejo and South Finland-Estonia. European Planning Studies, vol. 22, no. 7, pp. 1407-1424.

GorzelaK G., ZaWAlińsKa K. (eds.), 2013. European territories: From cooperation to integration? Warszawa: Wydawnictwo Naukowe Scholar.

Hsu J-Y., 2005. A site of transnationalism in the "Ungrounded Empire": Taipei as an interface city in the cross-border business networks. Geoforum, vol. 36, no. 5, pp. 654-666.

JONES R., 2009. Categories, borders and boundaries. Progress in Human Geography, vol. 33, no. 2, pp. 174-189.

Komornicki T., Miszczuk A., 2010. Eastern Poland as the borderland of the European Union. Quaestiones Geographicae, vol. 29, no. 2, pp. 55-69. 
Krok K., SmętKowski M. (ed.), 2006. Cross-border co-operation of Poland after EU enlargement. Focus on eastern border. Warszawa: Wydawnictwo Naukowe Scholar.

Lara-Valencia F., 2011. The "thickening" of the US-Mexico border: Prospects for cross-border networking and cooperation. Journal of Borderlands Studies, vol. 26, no. 3, pp. 251-264.

LEICK B., 2012. Business networks in the cross-border regions of the enlarged EU: What do we know in the post-enlargement era? Journal of Borderlands Studies, vol. 27, no. 3, pp. 299-314.

Miszczuk A., Kawatko B. (ed.), 2005. Pogranicze polsko-ukraińskie. Środowisko. Społeczeństwo. Gospodarka. Zamość: Wyższa Szkoła Zarządzania i Administracji.

Miszczuk A., 2015. Directions of Development of Tourism in the Polish-Ukrainian Cross-Border Area in the New European Union Programming Period (2014-2020) in the Context of Regional Planning Documents. Barometr Regionalny, 13/3, pp. 49-59.

OlejniCZAK K., 2008. Mechanizmy wykorzystania ewaluacji. Studium ewaluacji średniookresowych INTERREG III. Warszawa: Wydawnictwo Naukowe Scholar.

Olejniczak K., Ledzion B., Kościelecki P., PłoSzau A., Pander W., Domaradzka A., 2008. Ocena udziału polskich partnerów w projektach realizowanych w ramach programu INTERREG IIIB CADSES, Warszawa: EGO s.c., Ministerstwo Rozwoju Regionalnego.

PŁoszA A., 2013. Sieci instytucji otoczenia biznesu. Warszawa: Wydawnictwo Naukowe Scholar.

PŁoszA A., 2014. Inter-organizational network of cross-border cooperation in Podkarpackie Voivodship and Lviv Oblast, Warszawa: Euroreg.

Pотоскі J., 2009. Funkcje turystyki w kształtowaniu transgranicznego regionu górskiego Sudetów. Wrocław: Wydawnictwo Wrocławskiego Towarzystwa Naukowego.

Proniewski M., Proniewski M., 2008. Zewnętrzna granica Unii Europejskiej-Białoruś - możliwości wykorzystania dla dynamizacji procesów rozwojowych. Współpraca transgraniczna. Ekspertyza przygotowana na potrzeby Strategii rozwoju społeczno-gospodarczego Polski Wschodniej do roku 2020. Warszawa: Ministerstwo Rozwoju Regionalnego.
Provan K.G., Veazle M.A., Staten L.K.,TeufelSHONE N.I., 2005. The use of network analysis to strengthen community partnerships. Public Administration Review, vol. 65, no. 5, pp. 603-603.

PySARENKo S., 2016. Main directions of reforming the regional policy in Ukraine. Europa XXI, vol. 30, pp. 77-87.

Rudenko L., Lisovsky S., Maruniak E., Farion Y., 2016. Challenges and threats of Ukrainian spatial development on the way to European integration, Europa XXI, vol. 30, pp. 89-107.

SMĘTKOWSKI M., 2016. Spatial patterns of regional economic development in Central and Eastern European countries. Geographia Polonica, vol. 88, no. 4, pp. 539-555.

StRIHAN A., 2008. A network-based approach to regional borders: The case of Belgium. Regional Studies, vol. 42, no. 4, pp. 539-554.

SVENSSON S, 2013. Social capital and governance in European borderlands: A comparative study of Euroregions as policy actors. Budapest: Central European University [PhD Thesis].

Walther O., Reitel B., 2012. Cross-border policy networks in the trinational region of Basel. CEPS/ INSTEAD Working Paper No 2012-26.

Wasserman S., Faust K., 1994. Social network analysis: Methods and applications. New YorkCambridge: Cambridge University Press.

WesSelink E., BosChma R., 2017. European neighbourhood policy: History, structure, and implemented policy measures. Tijdschrift voor economische en sociale geografie, vol. 108, no. 1, pp. 4-20.

Wiering M., VerWIJMeren J., 2012. Limits and borders: Stages of transboundary water management. Journal of Borderlands Studies, vol. 27, no. 3, pp. 257-272.

WięCKOWSKI M., Michniak D., Bednarek-SZCZEpańska M., Chrenka B., Ira V., Komornicki T., Rosik P., Stępniak M., Székely V., Śleszyński P., ŚWIATtEK D., WIŚNIEWSKI R., 2012. Polish-Slovak borderland. Transport accessibility and tourism, Prace Geograficzne, 234, Warszawa: Instytut Geografii i Przestrzennego Zagospodarowania PAN.

WIECKOWSKI M., 2013. Eco-frontier in the mountainous borderlands of Central Europe. The case of Polish border parks. Journal of Alpine Research, vol. 101, no. 2. 
Vaishar A., Dvořák P., Hubačíková V., ZapletalOVÁ J., 2013. Contemporary development of peripheral parts of the Czech-Polish borderland: Case study of the Javornik area. Geographia Polonica, vol. 86, no. 3, pp. 237-253.

VAN HOUTUM H., 1999. Internationalisation and mental borders. Tijdschrift voor economische en sociale geografie, vol. 90, no. 3, pp. 329-335. van Houtum H., 2005. The geopolitics of borders and boundaries. Geopolitics, vol. 10, no. 4, pp. 672-679.

YeUnG H.W.-C., 1998. Transnational economic synergy and business networks: The case of two-way investment between Malaysia and Singapore. Regional Studies, vol. 32, no. 8, pp. 687-706. 